\title{
Os movimentos sociais e a mídia em tempos de globalização: um estudo das abordagens de jornais brasileiros e espanhóis sobre o MST e os Direitos Humanos'
}

The social movements and the media in times of globalization: a study of approaches of brazilian and spanish newspapers about the MST and Human Rights

FÁBIO SOUZA DA CRUZ

Professor do Programa de Pós-Graduação em Política Social e de graduação em Comunicação Social da Universidade Católica de Pelotas (UCPel). <fabiosouzadacruz@gmail.com>

\section{RESUMO}

Neste artigo, trabalhamos algumas problemáticas envolvendo a mídia tradicional, os movimentos sociais - em especial o Movimento dos Sem Terra (MST) - e os Direitos Humanos (DH) em tempos de globalização neoliberal, por meio de um estudo comparativo das edições online dos jornais Folha de São Paulo (Brasil) e El Mundo (Espanha), em 2010. Adotando uma postura crítica, histórica e dialética, fazemos uma intersecção entre esses objetos com o objetivo de problematizar questões e apontar possíveis saídas levando em consideração a urgência de um (re) pensar dos DH e o papel da mídia nesse cenário. Para tanto, utilizamos os pressupostos teóricos de Roland Barthes, Douglas Kellner, Joaquín Herrera Flores e David Sánchez Rubio.

Palavras-chave: Mídia; Direitos Humanos; Movimentos sociais.

\section{ABSTRACT}

In this article, we work some problems involving the tradicional media, the social movements - especially the Movement of the Agricultural Landless Workers (MST) and the human rights (DH) in times of neoliberal globalization, through a comparative study of the online editions of newspapers Folha de São Paulo (Brazil) and El Mundo (Spain) in 2010. Adopting a critical, historical and dialectical approach, we make an intersection between these objects in order to discuss both issues and pointing out possible alternatives considering the urgency of a (re)think the DH and the media's role in this scenario. In order to carry out the study, the theories of Roland Barthes, Douglas Kellner, Joaquín Herrera Flores and David Sánchez Rubio are taken into consideration. Keywords: Media; Human Rights; Social movements. 
Teste trabalho, faremos uma discussão em torno de dois elementos que se conectam 1 sobremaneira no cenário da globalização neoliberal: a mídia tradicional e os movimentos sociais. Mais especificamente, o que propomos nesta investigação é a realização de um estudo comparativo das versões online de dois jornais, o brasileiro Folha de São Paulo ${ }^{2}$ e o espanhol El Mundo ${ }^{3}$. Considerando isso, analisaremos a cobertura desses veículos no ano de 2010, período de eleições para presidente no Brasil, sobre o Movimento dos Sem Terra (MST), contemplando, como questão de fundo, a temática dos Direitos Humanos (DH).

Para tanto, inicialmente, traçaremos uma discussão envolvendo a globalização neoliberal - fio condutor deste estudo -, o papel dos veículos de comunicação nessa realidade, o MST e os DH com especial ênfase no cenário latinoamericano. Logo após, averiguaremos de que forma a mídia produz significado na atualidade, buscando identificar os elementos que influenciam suas construções. Nesse sentido, adotaremos os pressupostos teórico-metodológicos de Roland Barthes e Douglas Kellner.

Seguindo uma postura crítica, histórica e dialética, procuraremos, então, promover uma intersecção entre os nossos objetos de investigação por meio de um estudo comparativo, conforme mencionamos anteriormente. Partindo disso, pretendemos detectar semelhanças e diferenças nas abordagens dos veículos escolhidos para a análise. Outrossim, levantaremos uma discussão em torno de um (re)pensar dos DH na atualidade e do crucial papel da mídia nesse sentido. Salientamos, cabe ressaltar, que este trabalho não pretende generalizar resultados, mas, sim, detectar tendências e vislumbrar possibilidades em um determinado contexto com base em uma amostra de dados.

\section{O prelúdio da era global na América Latina e o papel centralizador da mídia, o MST e a questão dos Direitos Humanos}

A globalização traduz uma atmosfera comandada por empresas transnacionais - os chamados conglomerados econômicos -, pelo livre comércio e as privatizações. $\mathrm{Na}$ 
sua atual conjuntura, Estados Unidos, Japão e Europa Ocidental (principalmente a Alemanha) despontam como os principais nomes de força do processo, juntamente com as corporações transnacionais e organizações multilaterais. A partir desse cenário, o capitalismo global - ou neoliberalismo - agrava as contradições sociais em todos os setores e isso se dá mais fortemente "nos países dependentes, periféricos, atrasados, do terceiro mundo" (Ianni, 1995, p. 144).

Em vez de uma convivência sadia e respeitosa entre todos, da fraternidade e da liberdade, estamos vivenciando uma era em que os "valores centrais de nossa sociedade [...] são, em especial, a competitividade, a eficiência, a racionalização e funcionalização dos processos institucionais e técnicos" (Hinkelammert, 2011, p. 1). Assim, a nova ordem global recrudesce a desigualdade nos países em desenvolvimento, parte deles situada na América Latina. Consequentemente, esse fenômeno reforça o abismo existente entre os mais favorecidos e o resto da população.

Para Bauman (1999), com a globalização, o "tripé da soberania" (a autossuficiência militar, econômica e cultural) é afetado de maneira irreversível. A insuficiência militar é agravada frente às dificuldades sociais, como o desemprego, por exemplo, que corroboram, dentre outros fatores, o recrudescimento da violência e a insegurança, conforme tratado antes. Com relação ao aspecto cultural, a avalanche da indústria cultural, em todos os seus níveis e estilos, fomenta uma sociedade do consumo que é alimentada constantemente por produtos feitos sob medida e com curto tempo de duração ${ }^{4}$ e apreciação, conforme salienta García Canclini (1995). Já na área econômica, devido à pujança dos mercados financeiros globais, o Estado perde sua força, ficando reduzido ao âmbito político ${ }^{5}$.

Nesse cenário, definitivamente, os meios de comunicação de massa consistem no principal ou, na pior das hipóteses, em um dos principais agentes de mediação da sociedade. Por meio de textos, sons e imagens, a cultura midiática corrobora, assim, 
um fortalecimento dos laços sociais ao mesmo tempo em que fornece elementos de homogeneização de discursos e identidades.

Nesse sentido, a mídia tradicional latinoamericana e, em especial, a brasileira - um dos focos deste trabalho - constrói mitos e estereótipos, sugere regras, maneiras de pensar, modas e hábitos. Por trás desse véu sedutor, busca audiência e, consequentemente, lucros cada vez maiores. Para isso, lança mão de uma mistura de elementos oficiais com outros, nem sempre palatáveis como, por exemplo, o fait divers ${ }^{6}$.

Passando à frente de instituições como a família, a escola e a igreja, os meios de comunicação de massa, por meio de seus veículos, adquirem caráter centralizador na atualidade. Nessa realidade, muitas vezes, atuam em compasso com as forças hegemônicas da sociedade. Considerando isso, percebemos que a ideologia ${ }^{7}$ trans- $^{-}$ mitida nesse caso "é (geralmente) a do branco masculino, ocidental, de classe média ou superior; são as posições que vêem raças, classes, grupos e sexos diferentes dos seus como secundários, derivativos, inferiores e subservientes"' (Kellner, 2001, p. 83).

Levando em conta essa realidade, percebemos que a mídia tradicional latinoamericana consiste em uma espécie de palco por onde desfilam as mais diversas forças da sociedade. Nesse horizonte definitivamente político, os veículos de comunicação de massa reproduzem os embates entre os setores hegemônicos e contra-hegemônicos ${ }^{8}$ - ou de resistência.

Assim, quando trata de assuntos como a questão dos movimentos sociais - e mais especificamente do MST -, percebemos que, em geral, a mídia tradicional brasileira mantém-se de braços dados com determinadas forças hegemônicas da sociedade. Assim, governos de oposição ao Movimento, ruralistas, a justiça e o empresariado são blindados. Concomitantemente, o MST é visto como uma organização de delinquentes com propósitos atrasados, os quais têm a simpatia de alguns partidos de esquerda ${ }^{9}$, e que andam em descompasso com a realidade neoliberal globalizante. 
A cumplicidade da mídia tradicional latinoamericana com setores hegemônicos da sociedade é, nesse exemplo brasileiro, reforçada por um discurso que instaura o medo por meio do espetáculo e da omissão e/ou manipulação de informações. Dessa forma, a cultura midiática acaba, também, legitimando ações mais duras ${ }^{10}$ sobre o MST por parte do Estado, da polícia, da justiça e até mesmo dos ruralistas. Essa colocação é reforçada sobremaneira por Gallardo (2006, p. 49), que afirma: “o Estado de direito latino-americano é um simulacro, não uma realidade, e esta aparência e manobra é potencializada pelos meios massivos, a tolerância internacional e as igrejas"11.

Cenários totalmente opostos, a mídia tradicional brasileira e o MST podem, de certa forma, interseccionarem-se. Esse fenômeno pode ocorrer, por exemplo, quando ambos lidam com uma questão inerente à realidade dos Sem Terra e que, por outro lado, deveria ser pauta constante e obrigatória na agenda dos veículos de comunicação: os Direitos Humanos (DH).

Considerada uma das peças fundamentais para a "consolidação das democracias [...] (e o) desenvolvimento de todas as nações adeptas, ao menos formalmente, deste regime" (Canela, 2008, p. 11), a mídia tradicional deveria problematizar a complexa questão dos DH. Problematizar consiste em reconstruir historicamente os cenários para que possamos entender as suas práticas. Significa detectar qual é a lógica vigente, quais são os atores envolvidos no processo e de que forma se dão as suas relações.

Porém, não é isso o que percebemos em boa parte da cobertura dos veículos de comunicação de massa. Geralmente, detectamos que a mídia utiliza uma noção simplificadora dos DH, lançando mão de uma visão universal racionalmente formal, libertando a problemática dos DH de seu histórico impuro e injusto. Assim, os meios tradicionais massivos encaram essa temática como uma questão que se resume a direitos fundamentais, bens naturais como, por exemplo, o direito à sobrevivência, e também ao âmbito normativo-jurídico. 
Entretanto, acreditamos que esse conceito simplificado que se instaura no imaginário social ocidental não leva em conta um determinado e sempre complexo contexto sócio-histórico (e político) dos $\mathrm{DH}$, conforme mencionado anteriormente. É preciso (re)pensar ${ }^{12}$ os DH, dispensando atenção aos aspectos regionais como, por exemplo, os relacionados à América Latina. É preciso (re)pensá-los “desde um plano de imanência - um corte transversal da realidade - onde convivam (harmoniosamente) diferenças, distinções e disjunções ${ }^{13}$ radicalmente opostas a toda uniformidade e homogeneização do mundo" (Herrera Flores, 2005, p. 46).

Pensar, portanto, de outro modo significa, então, problematizar a realidade. Significa tensionar forças distintas em contextos ${ }^{14}$ particulares. Significa "estabelecer vínculos, conexões, redes rizomáticas, nós que nos facilitem os encontros com os demais" (Herrera Flores, 2005, p. 237).

Para Sánchez Rubio (2010, pp. 11-12), a origem ou o aparecimento de um direito humano apresenta, em linhas gerais, algumas etapas, a saber: a perda da dignidade humana em qualquer nível devido a contextos de exploração, opressão e desigualdade; há uma conscientização da situação por parte do grupo afetado; esta noção do problema vai ganhando força por parte desse grupo, o qual inicia uma resistência frente à situação; são tomadas decisões de cunho revolucionário que poderão triunfar; e, por fim, se o objetivo for alcançado, são desenvolvidos "ideais, conceitos e teorias de todo tipo", os quais servirão de bandeira em nível filosófico, ideológico, cultural e doutrinal para o movimento.

Voltando essa questão para a realidade latinoamericana ${ }^{15}$, na prática, sabemos que a questão em torno dos DH fica reduzida, conforme colocado anteriormente, aos interesses de forças hegemônicas da sociedade. São justamente esses agentes sociais que promovem a exclusão dos chamados populares ${ }^{16}$, ou seja, os blocos vulneráveis como, por exemplo, os pobres e os trabalhadores dos setores rurais (Gallardo, 2006). 
Princípio da injustiça, a exclusão pressupõe, assim, admitir um não-pertencimento a um grupo civil que pertence a uma determinada comunidade ${ }^{17}$ (Villoro, 2000).

É verossímil dizer que, desde as ideologias naturais sobre $\mathrm{DH}$, foram criadas categorias de não-pessoas, "ou seja, indivíduos, setores sociais ou povos e culturas que carecem desses direitos e de todo direito" (Gallardo, 2006, p. 7) e que são tratados como meras "distorções de mercado". Disso, resulta uma total falta de respeito às diferenças. Sendo assim, agora, os "anormais", esses seres indesejados que insistem em resistir, deverão ser aniquilados. Esse pensamento gera um verdadeiro "terrorismo de Estado", de onde são criados cenários que visam favorecer a manutenção da ideologia neoliberal da globalização (Hinkelammert, 2010).

Infelizmente, percebemos, assim, que essa realidade está longe de desaparecer devido ao atual contexto sócio-histórico trabalhado aqui. No entanto, é urgente promover mudanças. Estas, obrigatoriamente, implicariam alterações na atual economia, pois, sem isso, a sobrevivência da própria humanidade ficará ameaçada. O cenário latinoamericano, de notável assimetria social, projeta novas discussões. A negação do "padrão de normalidade" da justiça e a conseqüente exclusão ${ }^{18}$ como injustiça fazem emergir "um novo sujeito moral", que fará frente ao sujeito "normal" e que projetará "um novo modelo de justiça" (Villoro, 2000, p. 111), mais justo e igualitário, defensor de "uma igualdade na diferença" (Sánchez Rubio, 2011, p. 14), modelo este que pode e deve ser universalizado.

\section{Por uma teoria social crítica da mídia: o arcabouço teórico- metodológico de Douglas Kellner ${ }^{19}$ e Roland Barthes ${ }^{20}$}

De acordo com o que foi levantado anteriormente, o palco midiático recebe as forças antagônicas - hegemônicas e contra-hegemônicas - da sociedade. A partir disso, procurando estabelecer e verificar as ligações entre os atores envolvidos no campo 
social, Kellner (2001) utiliza-se da articulação. Esse conceito traduz, portanto, um ponto importante, ligado ao estudo do processo de organização e produção do discurso dos órgãos de comunicação massivos em um determinado contexto. Somente assim, por meio de um minucioso exercício de reconstrução histórica dos fatores em jogo, será possível refletirmos, interpretarmos e explicarmos criticamente as questões relativas à cultura midiática, suas relações com o todo social e suas produções.

Toda e qualquer produção midiática pressupõe articulações de cunho interno. Assim, reconhecemos as visões de mundo da empresa de comunicação e do produtor de informação, ambas baseadas em contextos particulares. Respeitando determinadas regras e aspectos técnicos, consideramos, também, que um texto é constituído dentro de um gênero ${ }^{21}$.

Além disso, as relações externas dos produtores de informação e das empresas em que trabalham, em maior ou menor grau, também interferem no produto final - a informação. Tudo isso consiste em um processo complexo. Dessa forma, percebemos a importância dispensada às mediações e à contextualização dos fatos em uma atividade de investigação crítica, histórica e dialética.

Em um cenário em que a qualidade da informação é, muitas vezes, inversamente proporcional ao índice de audiência, o racional é, portanto, superado, com certa frequência, pelos desvios discursivos, pelo espetáculo, pelo conflito, pela instauração do medo e pela fantasia das imagens. Por meio da mídia, vislumbra-se uma realidade na qual o discurso noticioso é substituído por uma espécie de discurso publicitário ${ }^{22}$, que tem a pretensão de homogeneizar identidades, estereotipado e mercadológico, a-histórico e sem aprofundamento. Por isso mesmo, é desprovido de elementos para a reflexão, ou seja, os meios ficam impossibilitados de justificar os fins.

Ocorre, portanto, a primazia do "o quê" sobre o "como" e o "porquê", o que traduz um discurso carente ${ }^{23}$, superficial e, muitas vezes, unilateral, que fere a ética jornalística, 
pois não contempla todos os lados envolvidos em determinada questão. Nesse sentido, Kellner (2001, p. 149) salienta que "se deve prestar atenção ao que fica fora dos textos ideológicos, pois freqüentemente são as exclusões e os silêncios que revelam o projeto ideológico do texto".

Por conseguinte, vivenciamos na realidade midiática brasileira a cultura do efêmero; o triunfo do descartável. São veiculadas informações superficiais, com carência de substancialidade quando, por exemplo, a pauta são os DH. Nas notícias de variedades e nos talk shows, contemplamos o apogeu das fofocas e demais atrocidades midiáticas; nos programas de cunho investigativo, que buscam única e exclusivamente a audiência sob o véu falacioso da justiça, do ajudar pessoas, assistimos à banalização da violência. É, portanto, neste cenário de uma verdadeira "sociedade do infotenimento (Kellner, 2003, 2011a; 2011b), que considerável parte dos veículos de comunicação de massa fomentam o pensamento rápido e miserável, pobre e acrítico, ao mesmo tempo que - é sempre salutar lembrar - protegem determinadas forças da sociedade. Nesse sentido, uma das técnicas mais utilizadas é o fait divers, a informação sensacionalista.

Os "casos do dia" ou "fatos diversos" refletem o capitalismo contemporâneo que, por meio de seus significados e métodos, fornece elementos que tendem a relegar os indivíduos à passividade e à manipulação ao mesmo tempo que obscurece a natureza e os efeitos do poder vigente. Fomentando uma memória curta e efêmera, o fait divers reflete algumas das premissas da era globalizante: as informações devem ser líquidas e, ao mesmo tempo, devem atingir o emocional das pessoas.

Desse modo, as relações dessa categoria criada por Roland Barthes (1971) são constituídas pelo excepcional, pelo grotesco, que valorizam o espetacular e podem ser reduzidas em dois tipos básicos: causalidade e coincidência. Ambos apresentam subtipologias respectivas, direcionadas para a compreensão da excepcionalidade, condição do estabelecimento da noção de conflito. 
O fait divers de causalidade revela dois tipos: a causa perturbada, quando se desconhece, ou não é possível precisar a causa, e, ainda, quando uma pequena causa provoca um grande efeito; e a causa esperada, em que, quando a causa é normal, a ênfase desloca-se para a dramatis personae (personagens dramáticos), como, por exemplo, crianças, mães e idosos (Barthes, 1971, pp. 267-271).

$\mathrm{Na}$ causa perturbada, ocorrem fatos excepcionais, espantosos, que implicam perturbação, conflito. Há um efeito (o conflito surge daí). No entanto, a causa é desconhecida, imprecisa, ou, até mesmo, ilógica, sem sentido. Não obstante, uma pequena causa pode provocar um grande efeito. Há uma riqueza de desvios causais. Devido a certos estereótipos, esperamos uma causa e surge outra, mais pobre do que a esperada. Neste gênero de relação causal, há o espetáculo de uma decepção; paradoxalmente, quanto mais escondida, mais notada será essa causalidade.

Barthes (1971, pp. 271-274) divide o fait divers de coincidência em dois tipos: de repetição - quando a informação repetida leva a imaginar causas desconhecidas, que ocorrem em circunstâncias diferentes - e de antítese, quando se aproximam dois termos qualitativamente distantes. A antítese une dois termos opostos, como se nunca tivessem sido, estabelecendo a noção de conflito, disponibilizando a emocionalidade. Em cada termo, pertencendo a um percurso autônomo de significação, a relação de coincidência apresenta, como função paradoxal, fundir dois percursos diferentes em um percurso único.

Baseado nas premissas trabalhadas até aqui, Kellner propõe o que ele chama de "alfabetismo crítico" (1995) ou "pedagogia crítica da mídia" (2001). Tal perspectiva teórico-metodológica significa um novo olhar - crítico - sobre a mídia, o qual promoveria uma tonificação do receptor com relação às produções desta. 
Sustenta o autor que uma leitura crítica das produções oriundas dos veículos de comunicação de massa deve ser feita de forma política ${ }^{24}$ o que refletirá o cenário de práticas e discursos da sociedade. Consequentemente, torna-se também imprescindível e ao mesmo tempo enriquecedor investigar, de maneira interdisciplinar ${ }^{25}$, os sentidos que a cultura da mídia fabrica e, ainda, quais os movimentos contra-hegemônicos que se dão sobre tais construções.

Portanto, ao estudar as produções midiáticas sob o prisma das relações entre ideologias, movimentos sociais e o contexto que os envolvem, inspirado pelo sociólogo Robert Wuthnow, Kellner (2001) lança mão de três categorias, a saber: horizonte social, campo discursivo e ação figural.

O horizonte social diz respeito às múltiplas relações, às práticas e experiências que se desenvolvem dentro do campo social, e que acabam, dessa forma, por contextualizar o local, a época e o cenário em que se dá a produção da cultura da mídia. O campo discursivo contempla as mediações, nas quais estão presentes todos os elementos (incluindo, aqui, os atores hegemônicos e contra-hegemônicos, dominantes e dominados, superiores e inferiores) envolvidos no discurso dos veículos de comunicação de massa. Já a ação figural implica mostrar os desdobramentos sociais de acordo com o horizonte social e o campo discursivo.

Tendo em vista esse mapa analítico, nos estudos da cultura da mídia propostos por Kellner (2001), em uma determinada circunstância social e histórica, são analisados, portanto, o modo de produção da informação, a mensagem propriamente dita, que é distribuída através de um canal, a recepção ${ }^{26}$ desta pelos públicos - também dentro de um contexto específico - e os efeitos do texto nesse público. Não obstante, de acordo com o que foi colocado na introdução deste trabalho, pretendemos ampliar essa análise, levando em conta, agora, além da mídia tradicional brasileira, a mídia tradicional internacional em um estudo comparativo. 


\section{Análises}

O grande intuito dessa comparação, salientamos, é verificar se a cobertura midiática brasileira, no que tange às questões que envolvem o MST e os DH esboçadas ao longo deste trabalho, tem sintonia com a cobertura que é feita pela mídia espanhola. Organizamos, para tanto, o nosso corpus da seguinte forma: considerando "MST" como palavra de busca nos sites dos jornais, foram colhidas matérias produzidas pelos dois veículos espanhóis ao longo do ano de 2010, período de eleições presidenciais no Brasil ${ }^{27}$.

Detectamos, assim, duas notícias veiculadas pelo El Mundo - nos dias 19 de abril e 31 de outubro. A partir disso, selecionamos as matérias da Folha de São Paulo, que correspondiam às produzidas pelo jornal espanhol, levando em conta um período de tempo anterior de até uma semana do dia em que estas foram veiculadas.

\section{Montando o quebra-cabeça}

Comecemos com uma constatação: unir, em uma só equação, elementos aparentemente tão díspares quanto os que estão em jogo não se constitui em uma tarefa simples. Trabalhar mídia, movimentos sociais e DH - reconhecemos - implica flertar com a complexidade. Entretanto, podemos vislumbrar alguns pontos de intersecção que, cuidadosamente, procuraremos explorar neste momento.

No que tange às matérias produzidas pelos jornais Folha de São Paulo e El Mundo em suas versões online, enxergamos um horizonte social permeado pela globalização neoliberal e algumas de suas consequências sombrias como a pobreza, a fome e o desemprego. Esse cenário também sugere relações de poder entre atores/forças hegemônicos e contra-hegemônicos da sociedade. Nesse campo discursivo, verificamos a presença dos Sem Terra, de governos estaduais e do Governo Federal, da mídia tradicional, dos latifundiários e de partidos políticos de esquerda e de direita ${ }^{28}$. Já a 
ação figural apresenta inúmeros desdobramentos. É a partir dessa categoria de análise que podemos detectar o viés político dos veículos midiáticos analisados.

Com relação à primeira matéria, intitulada "Os campesinos Sem Terra ocupam várias sedes do Instituto de Reforma Agrária"29, referente a um conflito envolvendo integrantes do MST e o INCRA (Instituto Nacional de Colonização e Reforma Agrária), percebemos que o El Mundo adota uma postura bem próxima da isenção com relação aos atores em jogo. Na reportagem, são informados todos os elementos básicos de um lead jornalístico.

Com o objetivo de exigir maior agilidade do Governo Federal com relação aos assentamentos dos campesinos, os Sem Terra ocuparam sedes do INCRA situadas em algumas capitais brasileiras, incluindo a Federal. O principal motivo alegado consistiu no descaso do poder público. Além disso, foram comentados supostos atos de violência por parte dos latifundiários sobre famílias de camponeses que estavam acampadas à beira das estradas.

Em um ano importante para o País, de eleições presidenciais, uma matéria envolvendo um movimento social como o MST e, consequentemente, a questão dos $\mathrm{DH}$ pode implicar em muitas possibilidades. Nesse caso específico, o que percebemos foi um tom discursivo favorável aos Sem Terra e desfavorável ao Governo Federal.

Não ouvindo os latifundiários, tampouco representantes do poder executivo, o El Mundo lança mão do fait divers de coincidência por meio do subtipo antítese ao retratar os integrantes do MST como vítimas, unindo, assim, dois percursos diferentes em um só. Tal concepção é reforçada pela foto que ilustra a reportagem. Notamos, também, que o termo utilizado pelo jornal espanhol para as ações do Movimento foi "ocupação", o qual se assemelha mais à concepção dos Sem Terra.

Mesmo não privilegiando todos os lados envolvidos na questão, acreditamos que, de certa forma, o El Mundo abordou na primeira matéria analisada as temáticas 
envolvendo o MST e os DH de forma pertinente. Mesmo tendo ficado longe de dar conta do intrincado processo que gira em torno dessas temáticas, ao colocar na berlinda esses objetos relevantes e sempre atuais, chamou a atenção de seus leitores para a complexidade desse verdadeiro jogo político que tenciona forças antagônicas da sociedade.

Do outro lado da moeda, ao cobrir a mesma notícia, a Folha de São Paulo lança mão de uma postura totalmente contrária à adotada pelo El Mundo. A começar pela primeira matéria, do dia 17 de abril ${ }^{30}$, constatamos a ausência dos porquês da "invasão" - termo adotado em toda a cobertura - dos Sem Terra às sedes do INCRA. Essa observação implica duas constatações que se interligam: a partir de um lead superficial, verificamos a presença do fait divers de causalidade por meio do subtipo causa perturbada, uma vez que, ao não sabermos os motivos que levaram às ações do MST, ficamos impossibilitados de precisar/entender essas práticas.

Essa visão simplificadora e, portanto, deturpada da questão que envolve os Sem Terra e a temática dos $\mathrm{DH}$ recebe o reforço ${ }^{31}$ do fait divers de coincidência por meio do subtipo repetição ao constatarmos a produção de dez matérias sobre o assunto. Como consequência da presença dessa categoria, mesmo tendo em mente a informação de que o que motivou os integrantes do Movimento a "invadirem", os prédios do INCRA foi a reforma agrária, o receptor pode ser levado a imaginar causas desconhecidas. Assim, outras intenções poderiam estar por trás das ações do MST.

Ouvindo somente representantes do Governo Federal - do INCRA, neste caso e dos latifundiários - a CNA (Confederação Nacional da Agricultura) -, a Folha de São Paulo coloca-se ao lado das forças contrárias à causa dos Sem Terra, endossando o discurso destas. Nesse sentido, percebemos novamente a presença do fait divers de coincidência por meio do subtipo antítese quando os integrantes do MST são considerados invasores e criminosos. 
Baseando-nos nas dez matérias da Folha de São Paulo analisadas, percebemos que a concepção desse veículo sobre o MST e os DH não é tratada com a profundidade merecida, mas, sim, como caso de polícia. Reduzindo a complexidade que permeia essas temáticas a questões normativo-jurídicas, esse influente veículo de comunicação brasileiro fortalece os anseios particulares das forças hegemônicas da sociedade.

Voltemos, agora, as nossas atenções à última cobertura. Conforme mencionado antes, o El Mundo produziu nova matéria abordando o MST no dia do segundo turno das eleições para presidente do Brasil ${ }^{32}$. Noticiando um debate que havia sido realizado cinco dias antes - e que rendeu duas reportagens da Folha de São Paulo -, o jornal espanhol informou os temas tratados no confronto e afirmou que a disputa havia sido parelha e que Dilma Rousseff era a favorita para ganhar o pleito. Quando o assunto foi o Movimento, o El Mundo, a exemplo do que fez o veículo brasileiro, destacou o comentário de José Serra de que sua adversária se contradizia: ora vestia o boné dos Sem Terra, ora o tirava.

Bem mais completa, a cobertura da Folha de São Paulo mostra um José Serra tratando o MST como algo nocivo ao colocá-lo junto a temas como a corrupção. Em meio a outras acusações ligadas a assuntos diversos, o candidato do PSDB apresentou uma postura mais agressiva comparada aos debates anteriores. Nesse sentido, fez coro ao discurso de boa parte da mídia tradicional brasileira quando deu a entender que os Sem Terra consistiam em um movimento não social, mas, sim, político, patrocinado pelo governo Lula.

Reforçando essa nossa afirmação, na sequência, Serra ligou o Movimento dos Sem Terra a invasões e destruições. Rotulando-os, portanto, como contraventores, o candidato mostrou claramente que, na sua concepção, temas ligados ao MST e os DH são meros casos de polícia. Por outro lado, mesmo posicionando-se de forma contrária a algumas ações do Movimento, Dilma Rousseff deixou claras as diferenças entre ela 
e o seu rival: enquanto que para este o MST era caso de polícia, para ela, o Movimento era questão de política social.

Ao contrário da Folha de São Paulo, distâncias geográficas, ao que parecem, podem colaborar para uma diferente abordagem por parte do El Mundo que, além de demonstrar uma maior preocupação com a questão dos Sem Terra e os DH, reforça o caráter contraditório da mídia. Lembrando Kellner, constatamos, assim, que essa pode se tornar

um entrave para a democracia quando reproduz discursos reacionários, promovendo o racismo, o preconceito de sexo, idade, classe e outros, mas também pode propiciar o avanço dos interesses dos grupos oprimidos quando ataca coisas como as formas de segregação racial ou sexual, ou quando, pelo menos, as enfraquece com representações mais positivas de raça e sexo."

(2001, p. 13).

Em contrapartida, devemos ver a realidade não com olhos míopes, mas, sim, com bons olhos, e de preferência acrescidos de uma boa lupa. E para que serve uma lupa? Serve justamente para ampliar as coisas. Para torná-las mais visíveis. Portanto, embora possamos enxergar abordagens que privilegiam temáticas como o MST e os DH, por outro lado, em uma estrofe, os dois veículos cantam a mesma letra: de posse do material analisado, no geral, o discurso produzido pelos jornais não dá conta da complexidade dos assuntos em debate aqui. Isso é reforçado a partir do momento em que, em vez de problematizarem, os veículos lançam mão de discursos "publicitários", 
"carentes", simplificando questões delicadas utilizando-se, inclusive, de técnicas como o fait divers, de fácil consumo, as quais servem apenas para manter a engrenagem funcionando.

Como salienta Sánchez Rubio (2007, p. 21), “quando falamos em direitos humanos na América Latina, reconhecemos a distância entre o discurso que o promove e a sua prática". Não obstante, nesse contexto, são estabelecidas algumas categorias que determinam as classes de sujeitos, a saber: "pessoa", "cidadão" e "capaz de trabalhar". Quem não se "encaixa" em alguma delas, é excluído, como é o caso dos Sem Terra.

Obviamente, essa realidade acaba, então, sendo amplificada por parte dos veículos analisados. Em tal contexto, no qual a diferença entre o que se diz e o que se promove sobre DH é gritante, os excluídos lutam "pelo reconhecimento da dignidade humana (e da diferença). Esta pode conquistar-se, destruir-se e/ou perder-se em função da assimetria ou simetria estabelecida pelas forças sociais que se impõem" (Sánchez Rubio, 2007, p. 27).

Com o apoio irrefutável de parte da mídia, o cenário descrito por Sánchez Rubio é justamente o que prevalece. Numa época de total contradição, vivenciamos, assim, aquilo que Hinkelammert chama de TINA (There is no alternative - em português, não há alternativas) (2010, p. 2). Portanto, agora, as resistências deverão ser aniquiladas. Nesse cenário, acabamos constatando muitas vezes que o tão falado ódio dos Sem Terra, na verdade, tem outro remetente: o mercado, o poder, setores da mídia e os latifundiários. Muitos desses, inclusive, são detentores de terras improdutivas, reflexo da desigualdade social brasileira.

O mundo é assim: o cenário é competitivo e altamente discriminatório. Diferenças de gênero, classe, raça etc., muitas vezes, não são respeitadas. Nessa realidade, são as forças hegemônicas que decidem quem está dentro e quem está descartado do jogo. Quem não se encaixar no sistema como os Sem Terra estará fora e entregue à própria 
sorte. Consequentemente, aumentam a fome e a miséria. Recrudesce a violência. Instaura-se a crise.

É assim o mundo? Sim, assim é o mundo. Ou, se preferirmos dizer, assim está sendo o mundo. Entretanto, podemos inverter a lógica tecendo o seguinte questionamento: assim deve ser o mundo? Nesse sentido, não caberia perguntar se uma "não-pessoa", este ser vulnerável da sociedade, não deveria ter o mesmo acesso à justiça e à igualdade que o dispensado aos sujeitos "normais"? E mais: será que esse ser "anormal", que reivindica "direitos surgidos desde suas racionalidades e necessidades [e que] é debilitado, ridicularizado, inferiorizado, atenuado, eliminado ou ignorado" (Sánchez Rubio, 2010, p. 210), não deveria começar a ser respeitado por aqueles que regem este mundo?

A resposta natural para tais indagações seria o sim. Sim, assim pode $e^{33}$ ser o mundo. Nesse mundo, o "diferente" teria as suas diferenças respeitadas e a sua tão requerida participação "no aspecto concreto da vida social ou política de que foi excluído" (Villoro, 2000, p. 113) seria finalmente atendida ${ }^{34}$. Isso tudo se constitui em um mero sonho? Para os inflexíveis, o "sim" muito provavelmente seja a resposta. Para os simpatizantes da frase de Michel Serres - "não há progresso sem utopia" -, muito provavelmente o "não" seja a resposta.

É a partir dessa lógica utópica, mas possível, que devemos analisar o contexto em que nos encontramos. É necessário, assim, percebermos a questão dos DH levando em conta suas "tramas sociais". Nestas, em um verdadeiro jogo político, extremamente complexo, enxergamos forças sociais hegemônicas e contra-hegemônicas atuando e, nesse sentido, muitas vezes, "as múltiplas tribunas do poder se excedem provocando situações de exclusão, marginalização e discriminação" (Sánchez Rubio, 2007, p. 16).

Nesse horizonte dominado, ditado pelo mercado com o apoio irrestrito de considerável parte dos veículos de comunicação e que, por outro lado, apresenta um 
Estado claramente combalido, originam-se disparidades cada vez maiores em nosso planeta ao mesmo tempo que "as grandes corporações transnacionais de petróleo, das finanças ou das comunicações" (Herrera Flores, 2005, p. 36) enriquecem acelerada e ininterruptamente.

Por conseguinte, (re)pensar DH consiste, hoje, em tarefa extremamente necessária e urgente no atual e "intolerável" contexto globalizante de trevas. Não podemos cruzar os braços. Não há mais tempo a perder. É preciso agir. É preciso lutar pelo bem comum. É preciso lutar pela dignidade humana. É preciso antecipar o futuro, resgatá-lo e entregá-lo curado. Isso obrigatoriamente deve ser encarado como a "reação cultural mais importante que podemos levar a cabo (e que acarretará) o processo de humanização do humano", o que significa, portanto, resistir "às debilidades e passividades que marcam os planos de transcendência (seja Deus, seja a Razão, seja a História, seja o Mercado...)" (Herrera Flores, 2005, pp. 44-45).

É justamente aqui que devemos questionar a verdadeira função dos mídia. Neste sentido, chegamos a uma constatação: um (re)pensar os DH passa, obrigatoriamente, por um (re)pensar a mídia. Não basta somente contemplar a temática do MST e dos DH em sua agenda diária. Os veículos de comunicação de massa tradicionais brasileiros e estrangeiros - deveriam ir muito mais além. Para cumprirem com o seu dever de servir a sociedade de forma realmente esclarecedora e ética, embora este termo pareça um corpo cada vez mais estranho na atual conjuntura global, deveriam problematizar esses assuntos. Ao deturparem as causas reais das desigualdades, os veículos de comunicação de massa prestam um desserviço à sociedade e, ao mesmo tempo, sustentam a expansão irrestrita de acumulação de capital em tempos de globalização orientada pela agenda neoliberal, universalizando todo um fundamento ético-político liberal e individualista. 


\section{Considerações finais}

Ao que parece, a tendência de parte dos veículos de comunicação massiva em nível mundial é a de não cumprir com a sua verdadeira tarefa, que é a de informar de forma ética e democrática a sociedade. Ao agirem dessa maneira, assemelham-se à figura de um médico insano, que sai da sua casa para trabalhar e, ao chegar ao hospital, esquece que a sua função principal é a de salvar vidas.

Uma vez agendadas, pautas importantes como o MST e os DH deveriam ser problematizadas à exaustão e também fiscalizadas pela mídia. Entretanto, percebemos que este tratamento geralmente inexiste. Nesse sentido, ter responsabilidade social no ato de informar não significaria engajar-se nos movimentos sociais, levantando a bandeira de suas causas e fazendo um trabalho panfletário. Tampouco significaria manter-se ao lado das forças hegemônicas da sociedade. Significa trânsito e conduta livres. Livres de qualquer força (agente/ator) social. Condutas livres e objetivas, pois o que está em jogo é o serviço prestado ao cidadão.

Fomentamos, a partir desse cenário, uma discussão sobre o papel dos produtores da informação. Imaginemos o dia a dia de um profissional de comunicação encarregado de agendar notícias para o público receptor. Pensemos, agora, no contexto particular desse profissional da comunicação. Ele possui uma determinada visão de mundo, o que lhe confere um olhar particular sobre as coisas. Esse "lugar de fala" é tensionado com a visão de mundo da empresa na qual ele - o comunicador - trabalha. Nesse sentido, portanto, temos que levar em conta inúmeros fatores que estão presentes na hora de produzir uma informação, a saber: o preparo (ou despreparo) do profissional com relação ao assunto que ele abordará, o grau de afinidade da empresa com os atores envolvidos na notícia e as pressões internas - dos superiores dentro da própria empresa em que o comunicador atua - e externas - do poder e demais atores hegemônicos da sociedade como, por exemplo, os patrocinadores. 
Levando isso em consideração, ancorada pelas NTIC ${ }^{35}$, parte da mídia despeja uma série de técnicas diariamente com um certeiro objetivo: manter ou instaurar situações que beneficiem os setores hegemônicos da sociedade. O motivo é um só: em tempos de globalização, nada mais salutar do que se manter de braços dados com o poder e, neste caso específico, o poder reinante é o mercado.

Autêntica personificação do médico insano, parte da mídia tradicional fere a ética em nome do mercado. Retira da pauta ou trata de forma manipulativa questões fundamentais como o MST e os DH. Seja por falta de preparo de seus profissionais, seja porque é movida por interesses particulares atrelados ao poder, considerável parcela dos veículos de comunicação desinforma, ao invés de informar e, assim, contribui para o analfabetismo em nível global, "incluindo (inclusive) os operadores jurídicos e os profissionais do direito" (Sánchez Rubio, 2011, p. 2) ao mesmo tempo que deixa a estrada livre para o reinado do neoliberalismo em nível global.

Aqui também, no que se refere às abordagens dos veículos analisados, em questões que envolvem as práticas políticas do MST, percebemos bem clara a materialização do fait divers na produção da informação, em especial a partir do ocultamento das razões históricas que legitimam as estratégias por vezes mais incisivas do Movimento. Ocupações de propriedades rurais improdutivas e de prédios públicos, tratadas como fenômenos desconectados da história do latifúndio no Brasil e da relação incestuosa do Estado com as elites agrárias do País, são veiculadas como práticas ilícitas penais, violação do "sagrado" direito de propriedade privada, ao invés de compreendidos como práxis de um movimento social emergente na luta por $\mathrm{DH}$.

Mediante abordagens fragmentadas, marcadas por silenciamentos e por recortes conservadores, a mídia encobre o papel importante do MST na sua relação com os DH (fonte geradora e legitimadora) e cria uma imagem do próprio Movimento enquanto instância social que atenta contra os DH. Desde uma orientação liberal individualista, 
a mídia tradicional trabalha a imagem dos Sem Terra afastada da sua real identidade, de movimento social que afirma sua diferença em relação às concepções tradicionais de um mundo coisificado, que mercantiliza a vida e as relações em todas as suas dimensões.

É imprescindível, portanto, olhar de frente - e com os olhos bem abertos - o jogo político de forças antagônicas que envolvem os temas em discussão e que questione a realidade "visível" e sabidamente cruel dos DH. Chega dos "discursos carentes"; chega dos "discursos publicitários"; chega da "síndrome do médico insano". É preciso dar um basta nisso. Dar um basta e arrumar o presente para preparar um futuro melhor.

Dar voz e vez às "não-pessoas" não significa panfletagem em favor dos excluídos, tampouco estamos, aqui, abandonando o caráter sério e criterioso de uma investigação científica. Dar voz e vez às minorias, grupos sociais que lutam por uma vida mais digna, consiste em lançar mão de uma bilateralidade discursiva, em dispensar espaços iguais tanto aos "normais" quanto aos "anormais", os "diferentes". Agir dessa maneira denotará uma preocupação com a sociedade civil. Demonstrará que a mídia tradicional estará livre para exercer a sua real função: informar ética e democraticamente a sociedade.

Que esses veículos de comunicação de massa sejam a caixa de ressonância da sociedade e façam a ética sorrir. Que eles andem de braços e mãos dadas com ela. Que declarem todo o seu amor por e somente para ela. Sabemos que só isso não será o suficiente para reverter o perverso cenário atual. No entanto, devido ao incontestável poder que os mídias exercem hoje sobre as pessoas, essa mudança de postura poderá trazer avanços significativos e quiçá sem volta para as questões referentes aos DH. Conforme foi colocado, é necessário agir. É preciso realmente enxergar o presente e, assim, preparar um cenário saudável para todos: os "normais" de agora e os "normais" do futuro. 


\section{REFERÊNCIAS}

BARTHES, Roland. Ensaios críticos. Lisboa: Edições 70, 1971.

BAUMAN, Zygmunt. Globalização: as consequências humanas. Rio de Janeiro: Jorge Zahar, 1999.

BAUMAN, Zygmunt. Modernidade líquida. Rio de Janeiro: Jorge Zahar, 2001.

CANELA, Guilherme. A cobertura jornalística das políticas públicas sociais: elementos para debate. In CANELA, Guilherme (org.). Políticas públicas sociais e os desafios para o jornalismo. São Paulo: Cortez Editora, 2008.

CRUZ, Fábio Souza. A cultura da mídia no Rio Grande do Sul: o caso MST e Jornal do Almoço. Pelotas: EDUCAT, 2006.

CRUZ, Fábio Souza da; MOURA, Marcelo Oliveira de. Direitos humanos, movimentos sociais e mídia: apontamentos iniciais e subsídios para debate. Disponível em: <http://www.bocc.ubi.pt/pag/cruz-fabiomoura-marcelo-direitos-humanos-movimentos-sociais.pdf >. Acesso em: 23 jan. 2012.

GALLARDO. Helio. Derechos humanos como movimiento social. Bogotá: Desde abajo, 2006.

GARCÍA CANCLINI, Néstor. Consumidores e cidadãos. Conflitos multiculturais da globalização. Rio de Janeiro: UFRJ, 1995.

HABERMAS, Jürgen. Mudança estrutural da esfera pública. Rio de Janeiro: Tempo Brasileiro, 1984.

HERRERA FLORES. Joaquín. Los derechos humanos como productos culturales. Crítica del humanismo abstracto. Navarra: IPES, 2005.

HINKELAMMERT, Franz J. La transformación del estado de derecho bajo el impacto de La estratégia de globalización. Disponível em: <http://www.pensamientocritico.info/articulos/articulos-de-franz-hinkelammert/183-latransformacion-del-estado-de-derecho-bajo-el-impacto-de-la-estrategia-de-globalizacion.html>. Acesso em: 15 nov. 2011.

HINKELAMMERT, Franz J. Lo indispensable es inutil. Sobre la ética de la convivencia. Disponível em: <http:// Www.pensamientocritico.info/>. Acesso em: 10 jan. 2012.

IANNI, Octavio. A Sociedade global. Rio de Janeiro: Civilização Brasileira, 1995.

KELLNER, Douglas. Lendo imagens criticamente: em direção a uma pedagogia pós-moderna. In: SILVA, Tomaz Tadeu da. Alienígenas na sala de aula - uma introdução aos estudos culturais em educação. Petrópolis: Vozes, 1995.

KELLNER, Douglas. A cultura da mídia. São Paulo: EDUSC, 2001.

SÁNCHEZ RUBIO, David. Repensar derechos humanos. De la anestesia a la sinestesia. Sevilla: Editorial MAD, 2007. 
SÁNCHEZ RUBIO, David. Sobre el concepto de "historización" y una crítica a la visión sobre las (de) generaciones de derechos humanos. In: FRUTOS, Juan Antonio Senent de; GALIANA, José Mora (orgs.). Ignacio Ellacuría 20 años después. Sevilha: Instituto Andaluz de Administración Pública, 2010.

SÁNCHEZ RUBIO, David. Desafios contemporáneos del derecho: diversidad, complejidad y derechos humanos. Mimeo, 2011.

SOUZA, Mauro Wilton de. Recepção e comunicação: a busca do sujeito. In: SOUZA, Mauro Wilton de (org.). Sujeito, o lado oculto do receptor. São Paulo: Brasiliense, 1995.

THOMPSON, John B. Ideologia e cultura moderna. Petrópolis: Vozes, 1995.

VILLORO, Luis. Sobre el principio de la injusticia: la exclusión (VIII Conferencias Aranguren, 1999). In Isegoría. Madrid: Instituto de Filosofia, 2000. pp. 103-142.

\section{NOTAS}

1 Trabalho apresentado ao Grupo de Trabalho Comunicação e Cidadania do XXI Encontro da Compós, na Universidade Federal de Juiz de Fora, Juiz de Fora, de 12 a 15 de junho de 2012.

2 Disponível em: <http://www.folha.uol.com.br >.

3 Disponível em: <http://www.elmundo.es>.

$4 \mathrm{O}$ aspecto efêmero dessa cultura leva, portanto, ao pensamento de que nada é para sempre. Na modernidade líquida descrita por Bauman, o cenário é a curto prazo: instantâneo e cheio de oportunidades e escolhas. Segundo o autor (2001, p. 74), "para que as possibilidades continuem infinitas, nenhuma deve ser capaz de petrificar-se em realidade para sempre. Melhor que permaneçam líquidas e fluidas e tenham 'data de validade', caso contrário, poderiam excluir as oportunidades remanescentes e abortar o embrião da própria aventura".

5 De acordo com Cruz e Moura (2010, p. 5), “o 'ente estatal' dá lugar a novos atores - forças anônimas transnacionais produtores de ordem opressiva. Tais forças instituem originais espaços decisórios - novos sítios legislativos, executivos e jurisdicionais - estabelecendo lugares e formas diferenciadas de dominação e tirania".

6 Esta categoria barthesiana (1971) será trabalhada posteriormente.

7 Inerente a essa discussão, Thompson (1995) faz menção ao conceito de ideologia, articulando-o às formas como o sentido (significado) serve para estabelecer e sustentar relações (assimétricas) de poder em contextos específicos.

8 Fica clara, aqui, a influência da teoria gramsciana da hegemonia, que prega ser a cultura um autêntico campo de lutas entre diferentes forças. Essa abordagem pressupõe dominação e resistência dos sujeitos sociais em um mesmo sistema. Segundo Souza (1995, p. 26), “a teoria da hegemonia não elimina a prioridade 
da análise dos conflitos sociais e psicossociais, mas destaca os interlocutores do processo de negociação política no interior das classes sociais, identifica os espaços dessa negociação e, dessa forma, atualiza a análise das modernas interações entre infraestrutura econômica e superestrutura política, redirecionando a relação entre ideologia e cultura".

9 Em estudo anterior (Cruz, 2006, p. 198), constatamos que o MST era ligado constantemente ao governo do ex-presidente brasileiro Luís Inácio Lula da Silva, do Partido dos Trabalhadores (PT), visto como "estático e atarantado".

${ }^{10}$ Grifo nosso.

${ }^{11}$ Vale constatar que essa tendência de legitimar a violência como forma de resolução de conflitos ganha cada vez mais força na passagem do século XX para o século XXI principalmente através de ações norteamericanas contra diversas civilizações do Oriente. Por sua vez, Sánchez Rubio sustenta que é característico dos ocidentais construir cenários propícios às suas demandas: “(...) Reduzimos sua complexidade simplificando-a para poder abarcá-la e compreendê-la (...) Com as abstrações, omitimos seletivamente alguns elementos que consideramos secundários. Mediante as idealizações, adicionamos também, de maneira seletiva, características que não existem" (2007, p. 38).

${ }^{12}$ Em alusão à obra de Sánchez Rubio (2007).

${ }^{13}$ Cabe salientar que, para Herrera Flores (2005, p. 65), o reconhecimento da pluralidade e da multiplicidade de propostas e reações culturais leva o nome de "relativismo cultural".

${ }^{14}$ Sociais, políticos, econômicos, culturais etc.

${ }^{15} \mathrm{O}$ que não significa dizer que esse contexto não pode ser aplicado ao resto do mundo.

${ }^{16}$ Segundo Gallardo (2006, p. 15), “um setor ou indivíduo é caracterizado socialmente como popular porque ocupa um espaço gestado estruturalmente como de vulnerabilidade ou, o que é semelhante, sofre alguma assimetria ou relação constituída de império/sujeição também sistêmica".

${ }_{17}$ Com relação aos requisitos "exigidos" para pertencer a uma determinada comunidade de consenso, primeiramente, temos que levar em conta que esta é formada por pessoas (forças hegemônicas) com determinadas características definidas e são justamente essas características que definem quem será aceito ou não na associação. Assim, os excluídos (forças contra-hegemônicas) apresentam diferenças determinadas que os deixam alheios ao grupo "normal" e essas podem ser de diversos tipos (raça, gênero, pertencimento a um determinado ambiente e/ou classe social etc.).

${ }^{18}$ Villoro define a exclusão como sendo "a falta de coincidência entre a comunidade de consenso efetiva e outra comunidade possível de agentes morais" (2000, p. 114).

${ }^{19}$ De origem norte-americana, Kellner é um verdadeiro articulador de teorias que "tem seu lugar de fala nos movimentos de contracultura dos anos de 1960, na recessão da primeira metade da década de 1970 e na implosão da Rússia a partir de 1980. (...) Em seus estudos, o autor contempla os mais diversos textos provenientes da cultura da mídia. Tem como objetivo elucidar tendências dominantes e de resistência, 
vislumbrar perspectivas históricas e também analisar a forma como os meios de comunicação agem com vistas a influenciar a identidade dos indivíduos receptores" (Cruz, 2006, pp. 64-66).

20 Semiólogo estruturalista francês. Responsável pela teorização do fait divers.

${ }^{21}$ Televisivo, radiofônico, impresso etc..

${ }^{22}$ Grifo nosso. Aqui, fazemos menção à ausência de um lead jornalístico completo, ou seja, que apresente as informações básicas de uma notícia, a saber: "o quê?", "quem?", “quando?", “onde?”, "como?" e "por quê?".

${ }^{23}$ Grifo nosso.

24 "Significa não só ler essa cultura no seu contexto sociopolítico e econômico, mas também ver de que modo os componentes internos de seus textos codificam relações de poder e dominação, servindo para promover os interesses dos grupos dominantes à custa de outros, para opor-se às ideologias, instituições e práticas hegemônicas, ou para conter uma mistura contraditória de formas que promovem dominação e resistência" (2001, p. 76).

${ }^{25}$ Segundo o autor (2001, pp. 38-39), “a teoria social dialética estabelece nexos entre partes isoladas da sociedade mostrando, por exemplo, de que modo a economia se insere nos processos da cultura da mídia e estrutura o tipo de texto que é produzido nas indústrias culturais (...) a dialética é a arte de estabelecer nexos e relações das partes do sistema entre si e com o sistema como um todo. Portanto, uma teoria crítica da sociedade contém mapeamentos do modo como a sociedade se organiza como um todo, delineando suas estruturas, instituições, práticas e discursos fundamentais, e o modo como eles se combinam formando um sistema social".

${ }^{26}$ Para fins de esclarecimento, a recepção não será trabalhada neste artigo.

${ }^{27}$ Após obter a vitória no primeiro turno, a candidata Dilma Rousseff (PT) enfrentou o candidato José Serra (PSDB), no segundo turno, alcançando, mais uma vez, a preferência do eleitorado brasileiro. Por conseguinte, tornou-se a primeira presidente mulher da história do País.

${ }^{28}$ Considerada a questão de fundo deste trabalho, podemos acrescentar nessa lista os DH.

${ }^{29}$ Disponível em: <http://www.elmundo.es/america/2010/04/20/brasil/1271716489.html>.

${ }^{30}$ Disponível em: <http://www1.folha.uol.com.br/folha/brasil/ult96u722382.shtml>.

${ }^{31}$ Grifo nosso.

${ }^{32}$ Disponível em: <http://www.elmundo.es/america/2010/10/26/brasil/1288067220.html>.

${ }^{33}$ Grifo nosso.

${ }^{34}$ Portanto, um excluído seria reconhecido como um autêntico cidadão, os seja, "o sujeito de uma associação política, organizada como Estado, que lhe outorga direitos" (Villoro, 2000, p. 130).

${ }^{35}$ Novas tecnologias de informação e comunicação. 